KULTURA

i

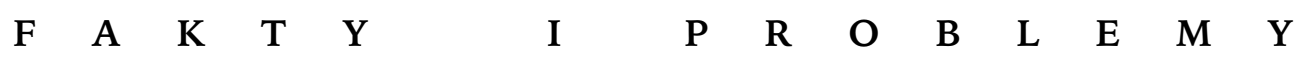

WIKTORIA CZYSTIAKOWA

ALEKSIEJ WASILIEW

Rosyjski Instytut Kulturoznawstwa

\title{
TRUDNE TEMATY PAMIĘCI POLSKIEJ I ROSYJSKIEJ: HISTORIOGRAFIA, LITERATURA, FILM
}

W październiku 2010 r. na Uniwersytecie Pedagogicznym im. Komisji Edukacji Narodowej w Krakowie odbył się międzynarodowy kongres poświęcony zagadnieniom kształtowania i funkcjonowania obrazów pamięci zbiorowej oraz różnych form narracji tożsamości narodowej ${ }^{1}$. Wydarzenie to stanowiło drugą część projektu regularnych międzynarodowych spotkań poświęconych dyskusji na temat pamięci społecznej (kulturowej) w stosunkach Rosji i Polski, w dużym stopniu naznaczonych obrazami przeszłości. Inicjatorem spotkań rok wcześniej został Rosyjski Instytut Kulturoznawstwa, który zajmuje się teoretycznymi i stosowanymi aspektami badań nad pamięcią (memory studies). W 2009 r. odbyła się w Moskwie, jako pierwszy krok w realizacji projektu, międzynarodowa konferencja naukowa „Rosja i Polska: dług pamięci i prawo zapomnienia” 2 . Jednym z głównych celów konferencji była analiza roli nauki historycznej i edukacji historycznej w procesach kształtowania i podtrzymywania tożsamości kulturowych Rosji i Polski oraz ich wpływu na stosunki polsko-rosyjskie. Zagadnienia te, jak również problem „obrazów-wspomnien”" zawartych w pamięci kulturowej i wywierających znaczny wpływ na więzi międzykulturowe i stosunki międzynarodowe, były omawiane podczas wszystkich obrad konferencji, łącznie z wydarzeniem specjalnym - spotkaniem z profesorem Andrzejem Walickim, uczonym światowej sławy, klasykiem współczesnej polskiej myśli humanistycznej i wybitnym przedstawicielem warszawskiej szkoły historii idei. Organiza-

Adres do korespondencji: v_chistyakova@mail.ru; vasal2006@yandex.ru

1 Międzynarodowy Kongres Naukowy „Polska-Rosja. Trudne tematy. Trzy narracje: historia, literatura, film”, Kraków, 5-7 października 2010 r.

2 Na temat tej konferencji zob. „Kultura i Społeczeństwo” 2009, nr 3, s. 209-212. 
torami konferencji były Rosyjski Instytut Kulturoznawstwa, Stacja Naukowa PAN w Moskwie, Uniwersytet Pedagogiczny im. Komisji Edukacji Narodowej w Krakowie, ambasada Rzeczypospolitej Polskiej w Moskwie, ambasada Stanów Zjednoczonych Ameryki Północnej w Moskwie, Francusko-Rosyjskie Centrum Nauk Humanistycznych i Społecznych w Moskwie, Instytut Niemiecki im. Goethego w Moskwie oraz wiele innych instytucji. W 2010 r. do grona organizatorów kolejnej konferencji z tego cyklu dołączyły Polskie Towarzystwo Historyczne, Muzeum Historii Polski, Katedra UNESCO ds. Badań Porównawczych Tradycji Duchowych, Specyfiki Kultur i Dialogu Międzyreligijnego przy Oddziale Rosyjskiego Instytutu Kulturoznawstwa w Sankt-Petersburgu. Uwaga uczestników krakowskiego spotkania była skupiona na porównywaniu form memorializacji kontrowersyjnych i problematycznych wydarzeń historycznych w stosunkach polsko-rosyjskich z wykorzystaniem metod historiografii, literatury pięknej i narracji filmowej.

Debata historyków w dużej mierze stała się kontynuacją zagadnień poruszanych na konferencji z 2009 r., dotyczących społeczno-kulturowych funkcji przeszłości, formy jej obecności i przekazu, korelacji pamięci i nauki historycznej, konieczności i możliwości ich rozdzielenia. W ubiegłym roku tematom tym poświęcone były wystąpienia profesora Uniwersytetu Virginii Alona Confino (Stany Zjednoczone) oraz profesor Loriny Repinej (Instytut Historii Powszechnej RAN), która w 2010 r. w Krakowie wystąpiła w roli moderatora ze strony rosyjskiej panelu „Historia”. Dyskusja dotyczyła kwestii konkurujących modeli tożsamości, kształtujących się $\mathrm{w}$ sferze publicznej $\mathrm{w}$ powiązaniu $\mathrm{z}$ różnymi obrazami przeszłości i projektami przyszłości, z różnymi celami politycznymi i pragmatycznymi. W związku z tym uaktualniła się rola historyków znajdujących się pod dużym wpływem nie tylko tradycji akademickiej, ale także środowiska społecznego. Kiedy i w jaki sposób realizowana jest krytyczna funkcja nauki historycznej i czy jest to w ogóle możliwe? Jak możliwe (i czy możliwe) jest korzystne, według Loriny Repinej, zdystansowanie historii od pamięci? Uczestnicy kongresu udzielali różnych odpowiedzi na pytanie o relacje między pamięcią, wiedzą o przeszłości a historią jako nauką.

Podczas obu spotkań z referatami na ten temat wystąpił jeden z czołowych przedstawicieli poznańskiej szkoły metodologicznej profesor Wojciech Wrzosek. W 2009 r. jego referat był poświęcony zaangażowaniu historii narodowej, problematyce wartości zawartych w klasycznej historiografii na poziomie dyskursywnych strategii prezentacji wiedzy. W 2010 r. rozważania profesora dotyczyły możliwości uniknięcia stronniczości historiografii narodowej i nawiązania bardziej owocnego dialogu na temat historii politycznej przez przyjęcie perspektywy kulturologicznej.

Jak podkreślała w swoim wykładzie Elena Jerochina (Syberyjski Oddział RAN), istnieje fundamentalna różnica między pamięcią historyczną a wiedzą historyczną: jeśli dla wiedzy historycznej zniekształcenie stanowi problem, który wymaga rozwiązania, to dla pamięci historycznej zniekształcenie, prze- 
sadne akcentowanie jednych wątków i lekceważenie innych jest naturalnym sposobem funkcjonowania. Aktualne priorytety zachęcają do eksponowania jednych faktów z przeszłości i ignorowania innych. Taka jest pragmatyka działań zbiorowych: aby społeczeństwo w okresie transformacji, do której jego członkowie mają różny stosunek, odnalazło jedność, potrzebuje wspólnego rozumienia wydarzeń i doświadczeń, które je ukształtowały. Wskutek tego powstają odmienne reinterpretacje wydarzeń przeszłości. Rozważania te stały się swoistą kontynuacją referatu autorki z konferencji wcześniejszej, poświęconego pamięci historycznej i tożsamości etnicznej. Autorka doszła w nim do wniosku, że uwaga poświęcana obecnie historii etnicznej wynika nie tyle z zainteresowania poznawczego, ile z pragnienia zachowania własnej tożsamości kulturowej, więzi emocjonalnej ze swoją wspólnotą w czasach radykalnych przemian.

Wymiarowi etycznemu opisywania historii, relacjom między myśleniem o przeszłości a odpowiedzialnością za teraźniejszość i przyszłość poświęcony był referat profesora Uniwersytetu Jagiellońskiego Krzysztofa Zamorskiego. Powołując się na koncepcje Reinharta Kosellecka i Agnes Heller, pokazał on, że w historiografii zawsze obecny jest horyzont teraźniejszości i perspektywa przyszłości. W epoce społeczeństwa informacyjnego, oplecionego siecią mediów elektronicznych, same formy wytwarzania, prezentacji i społecznego funkcjonowania wiedzy historycznej zmieniają się radykalnie. Zadaniem odpowiedzialnej historiografii jest natomiast refleksja na temat sposobów postrzegania jej wniosków.

Ważnym punktem wydarzeń w Moskwie i Krakowie była kwestia wzajemnych uprzedzeń i stereotypów Polaków i Rosjan. Z referatami na ten temat wystąpił profesor Uniwersytetu Łódzkiego Andrzej de Lazari. W 2009 r. jego referat był poświęcony wynikom projektu badawczego „Wzajemne uprzedzenia Polaków i Rosjan" przeprowadzonego przez Polski Instytut Stosunków Międzynarodowych w latach 2001-2004. Jednym z rezultatów projektu była publikacja Katalog wzajemnych uprzedzeń Polaków i Rosjan. W 2010 r. tematem jego wystąpienia stało się „zaprogramowanie kulturowe” jako źródło wzajemnego niezrozumienia. Autor podjął próbę zastosowania metodologii holenderskiego etnopsychologa Geerta Hofstede do przyjrzenia się problemom wzajemnego postrzegania Polaków i Rosjan przez pryzmat ich "programów kulturowych" oraz sformułował wniosek o istnieniu między nimi znacznego dystansu kulturowego.

Z perspektywy teoretycznej temat ten kontynuował profesor Wiktor Choriew (Instytut Słowianoznawstwa RAN) w wykładzie o imagologicznym aspekcie studiów nad pamięcią kulturową. Zauważa on, że imagologia otwiera szerokie perspektywy interdyscyplinarnej współpracy między naukami społecznymi i humanistycznymi w zakresie badania powstających w „wielkim czasie kultury” trwałych wzajemnych stereotypów. Stereotypy, ta „wiedza w pigułce”, według Janusza Tazbira charakteryzują nie tylko Innego, ale też nas samych, są one dosyć trwałe i sugestywne, łatwe do przyswojenia i trudne do kory- 
gowania. Wcześniej ich głównym źródłem była literatura (czego przykładem są wzajemne portrety Polaków i Rosjan stworzone przez Aleksandra Puszkina i Adama Mickiewicza). Dziś ich głównym dostawcą są media posługujące się obrazem. Stereotypy stanowią ważny element rzeczywistości historycznej, nawet jeśli są sprzeczne $z$ faktami historycznymi. Kierują się nimi ludzie w swojej działalności i - zgodnie z "twierdzeniem Thomasa” - postrzegane jako rzeczywiste stają się one rzeczywistymi w swoich konsekwencjach niezależnie od stopnia zgodności z rzeczywistością. Badając je, należy jednak pamiętać o zróżnicowaniu społecznym stereotypów w różnych grupach w obrębie tego samego społeczeństwa.

Aspektom systemowego i komparatywnego badania polsko-rosyjskich problemów historycznych XIX-XX wieku poświęcony był referat profesora Rosyjskiego Państwowego Uniwersytetu Humanistycznego Leonida Gorizontowa. W referacie zaznaczono ważność porównawczego podejścia do procesów w Rosji i w Polsce - podejścia pozwalającego dostrzec ogólne tendencje i uniknąć wzajemnej egzotyzacji.

Panel „Literatura” moderowany przez profesorów Tadeusza Budrewicza i Pawła Próchniaka (Uniwersytet Pedagogiczny im. Komisji Edukacji Narodowej w Krakowie) oraz profesora Wadima Rabinowicza (Rosyjski Instytut Kulturoznawstwa) reprezentowało na kongresie wiele znanych nazwisk z dziedziny literaturoznawstwa, krytyki literackiej, filologii, dziennikarstwa, teorii i praktyki przekładu, edytorstwa.

Zainteresowanie XVII wiekiem i odzwierciedlającymi je literackimi wątkami pojawiło się już na konferencji 2009 r. w sekcji „Memorialne kultury Rosji i Polski: wspólne i szczególne". Na krakowskim kongresie z referatami na temat 1612 roku i Wielkiej Smuty wystąpili filolog-polonistka Wiktoria Moczałowa („Polsko-rosyjski konflikt w XVII wieku w zwierciadle literatury rosyjskiej”), specjalistka w dziedzinie historii rosyjskiego kronikarstwa i historii tekstów narracyjnych Warwara Wowina („Obraz Polaków i obraz Rosjan w rosyjskich i polskich źródłach opowiadających o Smucie”), Magdalena Rudkowska z Polskiej Akademii Nauk („Kraszewskiego spory historiozoficzne z Rosjanami”), pracownik Stacji Naukowej PAN w Moskwie Piotr Głuszkowski („Wielka Smuta w sporze Puszkina i Bułharyna") oraz inni badacze. W referatach stwierdzono, że w późniejszym okresie - pod koniec XVIII i w pierwszych trzydziestu latach XIX wieku - literatura rosyjska również zwracała się do wydarzeń Wielkiej Smuty, poszukując tożsamości narodowej oraz próbując - poprzez retrospekcję historyczną — rehabilitować udział Rosji w rozbiorach Polski. Ponadto nie należy zapominać, że epoka Smuty to pierwszy przypadek pojawienia się w centrum Rosji dużej liczby cudzoziemców, przede wszystkim Polaków. Rosyjskie utwory o tym okresie obfitują w barwne obrazy "obcych”, trwałe stereotypy. Jednak pomimo stereotypów w sposobach postrzegania w tekstach można zauważyć nie tylko różnice, ale także lustrzane podobieństwo obrazów Polaków i Rosjan w polskich i rosyjskich powieściach z tego okresu. Jako negatywne ce- 
chy po obu stronach występują perfidia i okrucieństwo, a pochlebnie mówi się przede wszystkim o żołnierskiej odwadze i właściwym zachowaniu przeciwnika podczas wojny.

Jeszcze więcej referatów i debat poświęcono kontrowersyjnym wydarzeniom XX wieku oraz ich przedstawieniom w literaturze jako memorialnym krajobrazie. W panelu „Cezury 1917, 1918, 1920 w stosunkach polsko-rosyjskich” wystąpił slawista-literaturoznawca Wiktor Choriew z referatem „O mitologii odbioru Polski w Rosji” poświęconym rozpatrzeniu „mitu polskiego” i powiązanego z nim „mitu Europy”, który do końca XX wieku był w Rosji jednym z głównych obrazów historyczno-literackich. Profesor Andrzej Romanowski (Polska Akademia Nauk) wygłosił referat na temat „Poezja wojny polsko-sowieckiej 1920 roku”, w którym podjął próbę opisu poezji tego okresu jako fenomenu społecznego i ideowego, odwołującego się do tradycji literatury polskich powstań, zwłaszcza do poezji Legionów z okresu pierwszej wojny światowej. Analizie został poddany stereotyp „bolszewika” w kontekście funkcjonującego dotąd stereotypu „Moskala”. Autor zwrócił uwagę, po pierwsze, na te tendencje ówczesnej poezji (i rymowanej publicystyki), które znamionuje przenikliwość w odbiorze fenomenu bolszewizmu, a po drugie - na przejawy politycznego realizmu, próby refleksji nad stosunkami polsko-rosyjskimi po zakończeniu wojny. Szczegółowo w referacie omawiany był antyrosyjski charakter tych wierszy oraz ich oddziaływanie na narodową wyobraźnię. Inna odmiana poetyckiego doświadczenia została przeanalizowana $\mathrm{w}$ referacie Bogusława Gryszkiewicza (Uniwersytet Pedagogiczny im. Komisji Edukacji Narodowej w Krakowie) na temat „Literatura rosyjska w doświadczeniu polskiej awangardy poetyckiej międzywojnia (przykład Aleksandra Wata i jego współtowarzyszy)". Nie przecząc opinii o silnym, wielostronnym oddziaływaniu rosyjskiego futuryzmu na jego polski odpowiednik, badacz jednocześnie pokazał (na przykładzie twórczości poety Aleksandra Wata oraz jego literackich przyjaciół Anatola Sterna i Adama Ważyka), że sfera „wschodnich” zainteresowań przedstawicieli polskiej awangardy była o wiele rozleglejsza. Obejmowała również dokonania rosyjskiej klasycznej literatury XIX wieku. W poszukiwaniu odpowiedzi na pytanie, dlaczego właśnie tych twórców, uczestników ruchu awangardowego lat dwudziestych XX wieku, w niedalekiej przyszłości także wybitnych tłumaczy i krytyków literatury rosyjskiej w Polsce, wyróżniała wyjątkowa otwartość wobec kultury, która w zbiorowej świadomości Polaków wywoływała w najlepszym wypadku odczucia ambiwalentne, autor referatu zwraca uwagę na dwa czynniki. Po pierwsze, znaczenie miało ich poczucie przynależności do ponadnarodowej wspólnoty artystycznej, w której uczestniczenie wydawało się ważniejsze od więzi ze swoją lokalną kulturą. Po drugie, należy zaznaczyć determinującą to poczucie logikę procesów asymilacyjnych, która w przypadku wszystkich wspomnianych w referacie twórców wykształciła „uniwersalistyczny model” oparty na społecznej, emocjonalnej i intelektualnej predyspozycji do działalności w przestrzeni międzykulturowej. 
Należy zaznaczyć, że temat recepcji rosyjskich twórców w literaturze polskiej lat dwudziestych i trzydziestych XX wieku i późniejszego okresu został znacznie szerzej potraktowany w porównaniu z konferencją 2009 r., na której wygłoszono tylko jeden referat, poświęcony modelowi zachowania awangardowego artysty stworzonemu przez Majakowskiego i jego transformacji w polskiej tradycji literackiej. Referat nazywał się „Majakowszczyzna. O przygodzie pewnego pokolenia (Woroszylski, Mandalian i inni)", a jego autorką była doktorantka Uniwersytetu Jagiellońskiego Małgorzata Szumna.

Temat drugiej wojny światowej w polskiej literaturze pięknej został podjęty $\mathrm{w}$ referatach kilku uczestników kongresu, w tym $\mathrm{w}$ dwóch o podobnych tytułach: „Rosja wkracza do Polski (w poezji Zbigniewa Herberta)” profesor Danuty Opackiej-Walasek (Uniwersytet Śląski) oraz „Rosja wkracza do Polski: 1939-1945 (w prozie Wiesława Myśliwskiego)” profesor Bogumiły Kaniewskiej (Uniwersytet im. Adama Mickiewicza w Poznaniu).

Zasadniczą osią, wokół której skupia się interpretacja poetyckiego obrazu Rosji wkraczającej do Polski w latach drugiej wojny światowej oraz skomplikowanych relacji etyczno-politycznych, będących konsekwencją tego faktu, stały się dwa wiersze Herberta: Odpowiedź i 17 września. W obu przypadkach najazd ZSRR na Polskę i płynące z niego skutki stawiają bohaterów lirycznych wobec konieczności dokonania tragicznych wyborów (być wiernym Ojczyźnie i pozostać czy wyemigrować do wolnego świata, pokonać w sobie gniew wobec najeźdźcy i nauczyć się wybaczać).

Autorka referatu o prozie Wiesława Myśliwskiego zauważyła, że od czasów romantyzmu w kulturze polskiej istnieją dwa biegunowo odmienne stereotypy Rosjanina. Obydwa są sugestywnie przedstawione w utworach Adama Mickiewicza. Jeden to nienawidzący Polaków, okrutny i pozbawiony skrupułów Nowosilcow z Dziadów. Drugi to ofiara rosyjskiej tyranii, człowiek miłujący wolność, naturalny sprzymierzeniec polskiej i ogólnosłowiańskiej walki „za naszą i waszą wolność", sportretowany w wierszu Do przyjaciót Moskali. Zarówno pierwszy, jak i drugi stereotyp jest odtwarzany w polskiej kulturze artystycznej aż do dziś, od Czterech pancernych po Katyń. Obrazy te, znakomicie mieszczące się w pojęciach „wielkiej historii”, nie przystają natomiast do kontekstów mikrohistorycznych. To właśnie nad nimi pracuje Myśliwski. Obraz Rosji i Rosjan przedstawiony $\mathrm{w}$ powieści Widnokrag oraz $\mathrm{w}$ innych powieściach tego autora jest zdecydowanie bardziej złożony, wymyka się stereotypom i nie poddaje się łatwej typologizacji.

W referacie Iriny Adelgejm (Instytut Słowianoznawstwa RAN) pod tytułem „Druga wojna światowa we współczesnej prozie polskiej” analizowano twórczość pisarzy urodzonych po wojnie i odbierających ją przez pryzmat różnych „warstw kulturowych”. Podstawą opowieści o młodej polskiej prozie lat dziewięćdziesiątych XX wieku staje się świat przedmiotowy, mit i język. Pisarze pierwszego dziesięciolecia XXI wieku (jak Sylwia Chutnik, Joanna Bator, Dorota Masłowska, Bożena Keff) zwracają się bezpośrednio do potworności 
wojennej rzeczywistości, przejawiania przez człowieka najgorszych cech oraz do „śladów” wojny — podnosi się problemy ukazania traum psychologicznych, zrozumienia problemu rewanżu. Kwestia wojennej przeszłości wpasowuje się w obraz pozajęzykowej świadomości współczesnego filistra, w dekonstrukcję polskiego etosu. Twórcy zastanawiają się nad reakcją agresji, zaprzeczeniem, pragnieniem pozbycia się ciążącego nad polską świadomością „brzemienia trupów".

Polsko-rosyjska problematyka $\mathrm{w}$ literaturze okresu socjalizmu została przedstawiona w referatach profesora Wadima Rabinowicza („Polska w rosyjskiej poezji radzieckiej”), docenta Rosyjskiego Państwowego Uniwersytetu Humanistycznego Olgi Rozenblum („Znaczenia «przeszłości ogólnej» i narodowo-kulturowe odrębności w poezji Bułata Okudżawy o Polsce (1960-1990)”), docenta Petersburskiego Państwowego Uniwersytetu Lubow Bugajewej („Pamięć jako narracja: «Warszawska melodia» i kontekst historyczno-literacki”), doktora habilitowanego Tadeusza Sucharskiego („«Trudny temat» Rosji w literaturze polskiej po 1945 roku - próba inwentaryzacji problemów") oraz $\mathrm{w}$ innych referatach. W wykładzie Bugajewej pamięć rozpatrywana jest jako struktura mająca na celu pokonanie swojego zamknięcia poprzez narratyzację doświadczenia. Funkcja pamięci autobiograficznej w tym przypadku polega na gromadzeniu osobistych doświadczeń i dzieleniu się tymi doświadczeniami $z$ innymi ludźmi. Wspomnienia są istotne dla teraźniejszości nie dlatego, że określają działania podmiotu w teraźniejszości, ale dlatego, że są dzielone $z$ innymi ludźmi. W sztuce Warszawska melodia (1967) Leonida Zorina prywatne ukazywane jest jako ogólne, jako doświadczenie dzielone $z$ innymi ludźmi. Budując określone relacje między przeszłością a teraźniejszością, czytelnik (lub widz) wprowadza do nabytych doświadczeń dodatkowe znaczenia (których, być może, nie było wcześniej), rekombinuje detale wydarzenia, tworzy narrację, która wyjaśnia trajektorię ruchu tożsamości, w tym historycznej. Historię miłości polskiej dziewczyny i radzieckiego chłopaka w latach powojennych w Związku Radzieckim można odczytywać zarówno w kontekście wydarzeń historycznych, które przesądziły o smutnym zakończeniu sztuki, jak i w szerszym kontekście stosunków polsko-radzieckich i procesów społecznych zachodzących w Polsce i ZSRR w następnych dziesięcioleciach.

Specjalna sesja „Literaturocentryczność a specyfika polskiej i rosyjskiej kultury pamięci" była poświęcona badaniu doświadczenia współczesnych tytułów literackich prezentujących Polskę w Rosji.

Spotkania i dyskusje filmoznawców (w ramach panelu „Film” oraz innych sesji) były poświęcone przede wszystkim omówieniu zagadnienia dokumentu audiowizualnego jako źródła historycznego. Dyskusję zapoczątkowali profesor Kiryłł Razłogow (Rosyjski Instytut Kulturoznawstwa) i profesor Władimir Magidow (Rosyjski Państwowy Uniwersytet Humanistyczny), którzy w trakcie pierwszej sesji plenarnej wyrazili przeciwstawne opinie w tej kwestii. „Film ma taki sam stosunek do źródła literackiego jak źródło literackie do rzeczywistości 
historycznej, to znaczy żaden" - powiedział Kiryłł Razłogow w plenarnym referacie „"Fałsz» i "prawda» filmu historycznego (doświadczenie analizy kulturologicznej)” poświęconym analizie relacji „prawdy życia” i „prawdy sztuki” w kinie. Władimir Magidow w wystąpieniu „Film jako źródło historyczne: problemy interpretacji i wykorzystania tekstu filmowego", przeciwnie, podkreślił ważność interpretacji i wykorzystania dokumentów filmowych w badaniach historycznych. Profesor zaznaczył, że problem wykorzystania tekstu filmowego łączy aspekty źródłoznawcze, archiwoznawcze, kulturologiczne i społeczno-psychologiczne. Dziś bardziej niż kiedykolwiek aktualne są pytania o autentyczność i wiarygodność dokumentów filmowych oraz o określenie terminologicznej podstawy ich badań. Ponadto należy określić miejsce tego typu informacyjnych zasobów w kształtowaniu jednolitej i kompleksowej wiedzy historycznej w zakresie najbardziej dyskusyjnych i jeszcze niewystarczająco zbadanych problemów historii, wśród których są polsko-rosyjskie stosunki od XVII wieku do dnia dzisiejszego. Omówienie tej problematyki kontynuowano w dyskusji o fenomenie ekranizacji i problemie fabularnego filmu historycznego, którą wywołał referat Aleksandra Małowa (Instytut Historii Powszechnej RAN) zatutułowany „"To spór jest Słowian między sobą...» odzwierciedlenie w kinematografii rosyjsko-polskiej konfrontacji w drugiej połowie XVI-XVII wieku". Autor mówił o filmie historycznym jako o głównym czynniku kształtowania lokalnej pamięci historycznej narodu oraz mitu narodowego. Polską ekranizację trylogii historycznej Henryka Sienkiewicza (Ogniem i mieczem, Potop, Pan Wotodyjowski) badacz określił jak najlepszy film historyczny o XVI-XVII wieku, z którym współczesne rosyjskie kino historyczne o tej epoce na razie nie może się równać. Referat stał się w pewnym sensie kontynuacją podjętego na konferencji w 2009 r. pytania o reprezentację wydarzeń historycznych w rosyjskim i polskim kinie fabularnym. Na moskiewskim spotkaniu tematowi temu poświęcony był referat pod tytułem „Sporny wiek XVII w kinie: «Ogniem i mieczem» i "1612»", wygłoszony przez doktora Martina Austa z Uniwersytetu Christiana Albrechta w Niemczech.

W referatach poświęconych odzwierciedleniu rosyjskiej rewolucji i wojny polsko-bolszewickiej roku $1920 \mathrm{w}$ kinie radzieckim i polskim analizowano i porównywano z jednej strony filmy $\mathrm{Na}$ czerwonym froncie (pierwszy film późniejszego „zespołu Kuleszowa”, półdokumentalny, półfabularny, w którym sam reżyser i jego partnerka Aleksandra Chochłowa grali polskich rolników wykonujących retoryczny rozkaz: „Bierz karabin, polski robotniku, i bij panów!”), Wyzwolenie ukrainskich i białoruskich ziem od ucisku polskich panów i ponowne połaczenie bratnich narodów w jedna rodzine (Aleksandra Dowżenki), Bohdan Chmielnicki (Igora Sawczenki), Pierwsza Konna (Jefima Dzigana). Przedstawiciel Instytutu Naukowo-Badawczego Sztuki Filmowej Siergiej Kaptieriew, porównując dwa ostatnie filmy w kontekście stosunków polsko-rosyjskich, zauważył, że oba należą do filmów poświęconych tematyce polskiej, powstałych w Związku Radzieckim po sowiecko-niemieckim rozbiorze Polski. Wywodzą się one z bardzo 
ważnych dla kina radzieckiego lat trzydziestych XX wieku modeli filmu historyczno-patriotycznego oraz filmu „obronnego”, które miały przygotowywać radziecką ludność do przyszłej wojny i demaskować jej potencjalnych sprawców. Jednak w nowej sytuacji politycznej służyły przede wszystkim usprawiedliwieniu okupacji sowieckiej i historycznemu uzasadnieniu jej słuszności. „Wroga” strona - polskie filmy o tym samym okresie historycznym - została przedstawiona w wykładzie Mariusza Guzka (Uniwersytet im. Kazimierza Wielkiego w Bydgoszczy) i Romana Włodka (Polska Akademia Nauk). W pierwszym referacie analizowano polskie filmy poruszające wątek wydarzeń roku 1917 i ukazujące je w narracji apokaliptycznej, jako burzące wartości, na których oparta była cywilizacja wraz z jej częścią - II Rzeczpospolitą: Krwawy terror (1920), Tragedia Rosji i jej trzy epoki (1921) Edwarda Puchalskiego, Przed sadem (1922) Antoniego Bednarczyka, Trucizna bolszewizmu (1924) i Bohaterowie Sybiru (1938) Michała Waszyńskiego. Filmy te tworzą obraz wrogiego, obcego, nasyconego demonicznymi postaciami świata rewolucyjnego zagrożenia. Drugi referat poświęcony był wojnie polsko-bolszewickiej, która stała się tematem filmowym już w trakcie jej trwania. Filmy, pełniąc ważne funkcje propagandowe, ukazywały odwagę Wojska Polskiego i mobilizowały do walki. Jednym z nich była produkcja Dla Ciebie, Polsko (reż. Antoni Bednarczyk), której premiera odbyła się 25 czerwca 1920 r. - niecałe dwa miesiące przed bitwą warszawską. Sama bitwa stanowi kulminację dwuczęściowego Cudu nad Wisłą (1921, reżyser Ryszard Bolesławski). W obu filmach wróg został przedstawiony schematycznie — jako odindywidualizowana, groźna masa.

Jednym z najbardziej popularnych tematów wystąpień była tragedia katyńska w kinie i twórczości Andrzeja Wajdy (który osobiście wziął udział w ostatniej sesji plenarnej kongresu i opowiedział historię powstawania filmu Katyń). W nurcie badań nad pamięcią kino Wajdy zostało przeanalizowane w wykładzie Borysa Rejfmana (Iżewski Państwowy Uniwersytet Techniczny) „Twórczość Andrzeja Wajdy: między "pamięcią zbiorową" a "historiografią"”. Autor rozpatrzył w nim polski i sowiecki totalitaryzm jako fenomen nowoeuropejskiego „świata przeżywanego" - jednego z głównych tematów twórczości Wajdy. Zauważył, że przy porównaniu filmów Popiót $i$ diament, Człowiek $z$ marmuru i Danton najbardziej wyraziście ujawnia się wywodząca się z konfrontacji racjonalistycznego wyrozumowanego „rozumu” i romantycznego egzystencjalnego „uczucia" ważna Wajdowska dychotomia ograniczonej lokalności i bezgranicznego rozwoju. Obydwa typy ludzkie odpowiadające tym typom nowoeuropejskiej indywidualizacji - tak jak zresztą wszyscy inni — nie potrafią żyć bez "pamięci zbiorowej”, z tym że „ograniczeni przez lokalność” twardo ustalają jej granice, a "rozwojowi” dążą do przekroczenia tych granic.

Pracę sekcji w ramach panelu „Film” na ostatnim plenarnym posiedzeniu podsumował profesor Uniwersytetu Jagiellońskiego Tadeusz Lubelski.

Wśród innych wydarzeń kongresu należy wyróżnić specjalny panel Polsko-Rosyjskiej Grupy Podręcznikowej „Wspólna historia jako potencjał konfliktu 
i współpracy. Polskie i rosyjskie podręczniki do historii". Inicjatorem, organizatorem i moderatorem panelu został dyrektor Stacji PAN w Moskwie profesor Mariusz Wołos. Rok wcześniej na konferencji w Moskwie problem podręczników był omawiany w ramach sekcji „Pamięć i praktyki edukacyjne w Rosji i Polsce". Głównym tematem rozmów na moskiewskich i krakowskich spotkaniach była zawartość rosyjskich i polskich podręczników do nauczania historii oraz tworzone przez nie w umysłach dorastającego pokolenia wzajemne obrazy dwóch krajów (referaty profesora Roberta Łosia „Obraz Rosji i Polski w podręcznikach i na lekcjach historii”, docenta Władimira Kutiawina „Polska historia we współczesnych rosyjskich podręcznikach: o polityce historycznej i mechanizmach tworzenia się historycznej pamięci", profesora Zbigniewa Karpusa „Relacje polsko-sowieckie i polsko-rosyjskie w XX wieku w aktualnej podstawie programowej i podręcznikach do nauczania historii w szkole średniej w Polsce" i inne). Podkreślano potrzebę aktywizacji działalności polsko-rosyjskiej komisji zajmującej się analizą podręczników do historii oraz uwzględnienia w jej działalności pozytywnego doświadczenia analogicznej komisji polsko-niemieckiej.

Posiedzenie plenarne kończące obrady kongresu było poświęcone pamięci Rajmunda Piotrowskiego (1922-2009), zasłużonego uczonego Federacji Rosyjskiej, doktora habilitowanego nauk filologicznych, profesora, Honorowego Prezydenta Stowarzyszenia Kulturalno-Oświatowego „Polonia” w Sankt-Petersburgu. Podczas wcześniejszej konferencji w Moskwie w 2009 r. specjalny program poświęcono pamięci zmarłej wówczas profesor Barbary Skargi (1919-2009).

W końcowym przemówieniu profesora Adama Rotfelda, Pełnomocnika Ministra Spraw Zagranicznych i Współprzewodniczącego Polsko-Rosyjskiej Grupy do Spraw Trudnych, zostały porównane poziomy wzajemnego zainteresowania obydwu krajów, Rosji i Polski. Zauważono, że politycznie Polska znacznie mniej interesuje Rosję niż Rosja Polskę. Jednocześnie polska kultura jest znacznie bardziej popularna w Rosji niż w jakimkolwiek innym kraju. W recenzji konferencji z 2009 r. w Moskwie profesor Andrzej Walicki również podkreślał, że ze wszystkich krajów świata tylko w Rosji konferencja poświęcona polskiej problematyce mogła zebrać taką liczbę zainteresowanych uczestników. Jednakże potencjał ten - jak zauważono w dyskusji po referacie — prawie wcale nie jest wykorzystywany do nawiązania międzypaństwowego dialogu.

Profesor Dmitrij Spiwak (Oddział Rosyjskiego Instytutu Kulturoznawstwa w Sankt-Petersburgu) w swoim referacie mówił o zasadności wykorzystania najważniejszych postanowień strategii rozwoju kultury UNESCO $\mathrm{w}$ ramach polsko-rosyjskiego dialogu na jego obecnym etapie. Strategia ta polega na wspieraniu i promowaniu różnorodności kulturowej, przeciwstawionej zarówno wyzwaniom globalizacji, jak i izolacjonizmu, w celu zapewnienia kultury pokoju, praw i wolności człowieka oraz twórczego i równoprawnego rozwoju kultur narodowych. Profesor Spiwak w swoim przemówieniu zapowiedział kontynuację cyklu wydarzeń naukowych poświęconych problematyce pamięci 
w ramach stosunków polsko-rosyjskich - kolejnym etapem będzie spotkanie w 2012 r. w Sankt-Petersburgu.

6 października 2010 r. w Gazeta Cafe „Gazety Wyborczej” w Krakowie odbyła się debata uczestników kongresu i szerokiej publiczności na temat stosunków polsko-rosyjskich. Ze strony rosyjskiej wzięli w niej udział profesor Leonid Gorizontow, profesor Dmitrij Spiwak, docent Aleksiej Wasiliew, a z polskiej profesorowie Andrzej Chwalba, Adam Rotfeld, Jacek Chrobaczyński. Podczas spotkania omawiano zagadnienia wzajemnych stereotypów, roli pamięci kulturowej w stosunkach między narodami i państwami, sposobów przełamywania barier nieporozumień.

Debata ta stanowiła w pewnym sensie kontynuację tej, która rozpoczęła się w 2009 r. w Moskwie podczas panelu dyskusyjnego „Francuskie spojrzenie na memory studies: metodologia badań”. Ogólny ton dyskusji nadał wtedy referat profesora Georgesa Minka (z Instytutu Socjologii Polityki Narodowego Centrum Badań Naukowych Francji) poświęcony geopolityce, „grom pamięci” i problemom pojednania międzyetnicznego.

Podsumowując wyniki zarówno moskiewskiego, jak i krakowskiego wydarzenia należy wyróżnić szereg referatów poświęconych ogólnym problemom badań nad pamięcią. Na konferencji w 2009 r. odbył się specjalny panel dyskusyjny „Memory studies: na drodze do «memorialnego paradygmatu» wiedzy społeczno-humanistycznej”. Na kongresie w 2010 r. „morfologii pamięci” oraz porównaniu różnych typów wspomnień były poświęcone referaty profesor Loriny Repinej (relacje pamięci indywidualnej i zbiorowej oraz ich wzajemne przenikanie) i profesora Macieja Bugajewskiego z Uniwersytetu Poznańskiego (relacje między pamięcią historyczną i pamięcią obywatelska). Na spotkaniu w 2009 r. o problemach specyfiki „kultur wspomnienia” oraz polityce pamięci traktowały referaty dyrektora Instytutu Historii Litwy Alvydasa Nikżentajtisa (porównanie modeli pamięci kulturowej Litwy, Polski, Rosji) i docenta Aleksieja Wasiliewa (analiza rozwoju memory studies w Rosji i Polsce oraz specyfika uprawianej $\mathrm{w}$ obu krajach polityki pamięci). Relacjom między pamięcią regionalną, pamięcią mniejszości narodowych oraz pamięcią narodową w 2009 r. był poświęcony panel dyskusyjny „Pamięć mniejszości i regionów: możliwość konfliktu czy źródło rozwoju. Doświadczenia rosyjskie i polskie". Przeanalizowane zostały rosyjskie, polskie i ukraińskie doświadczenia integracji „małych narracji” pamięci $\mathrm{w}$ „wielkie narracje” narodowej historii.

Badanie „wspólnych miejsc pamięci” to jeden z najbardziej aktualnych kierunków rozwoju „badań memorialnych”. W 2009 r. referat profesora Uniwersytetu Jagiellońskiego Andrzeja Chwalby był poświęcony polsko-rosyjskim „miejscom" wspólnej pamięci, autor podkreślał duże naukowo-teoretyczne i praktyczne znaczenie wspólnego ich badania. Przeanalizowano też doświadczenie analogicznego projektu polsko-niemieckiego pod kierunkiem profesora Roberta Traby. W 2010 r. problematyka „wspólnych miejsc” polsko-rosyjskiej pamięci $\mathrm{w}$ kontekście dialektyki pamięci i zapomnienia w kulturze została po- 
ruszona w wykładzie Niny Koczelajewej (Rosyjski Instytut Kulturoznawstwa). Problemom mediatyzacji pamięci kulturowej, specyfiki reprezentacji „obrazów-wspomnień" przez różne typy nosicieli pamięci, remediatyzacji wspomnień, przedstawianym konsekwentnie w literaturze historycznej i etnograficznej, utworach literackich i kinie, podczas spotkania w 2010 r. również poświęcono kilka wystąpień. W referacie docenta Aleksieja Wasiliewa (Rosyjski Instytut Kulturoznawstwa) rozpatrywane były medialne transformacje obrazów Białorusi i szlachty na materiałach ekranizacji powieści Władimira Korotkiewicza Dzikie polowanie króla Stacha, a w referacie Wiktorii Czystiakowej (Rosyjski Instytut Kulturoznawstwa) przeanalizowane zostały najnowsze procesy dekonstrukcji środkami filmowymi dyskursu o wrogości w stosunkach polsko-rosyjskich na przykładzie ekranizacji powieści Wojna polsko-ruska pod flaga biało-czerwona młodej polskiej pisarki Doroty Masłowskiej.

Wyrazem uznania tych spotkań za sukces może być fakt, że omawiany projekt międzynarodowych spotkań na temat pamięci zbiorowej w stosunkach Rosji i Polski został włączony przez UNESCO do listy wydarzeń 2011 r. prezentujących Rosję w ramach Roku Zbliżenia Kultur ${ }^{3}$.

\footnotetext{
${ }^{3} \mathrm{Z}$ materiałami obu międzynarodowych spotkań można zapoznać się na stronach Rosyjskiego Instytutu Kulturoznawstwa (http://www.ricur.ru/page.php?r=139\#rus-pol2009) oraz Uniwersytetu Pedagogicznego im. Komisji Edukacji Narodowej w Krakowie (http://www.up.krakow.pl/ main/kongres/).
} 